\title{
Effects of Long-Term Containment in Residential Spaces
}

\author{
Pashmeena Vikramjit Ghom and Abraham George* \\ Department of Architecture and Regional Planning, Kharagpur, India
}

*Corresponding author: Abraham George, Department of Architecture and Regional Planning, Indian Institute of Technology Kharagpur, India

\section{ARTICLE INFO}

Received: 蔧 July 02, 2020

Published: 幽 July 13, 2020

Citation: Pashmeena Vikramjit G, Abraham G. Effects of Long-Term Containment in Residential Spaces. Biomed J Sci \& Tech Res 28(5)-2020. BJSTR. MS.ID.004710.

Keywords: Long-term containment; Pandemic; residential spaces; Human behaviour; Preferences

\section{ABSTRACI}

Global events of pandemic have struck the world to standstill even before COVID-19. Its adverse effects are affecting normal life; particularly in the way societies function and relate to one another, spatial order, and normal business. Long-term containment, its effects on human behaviour is none less than the dwindling world economy. These ill-effects are reflected more in terms of spatial order, spatial standards, housing, and rehabilitation later, to reach a new normalcy. It calls for challenges in social and individual's behaviour in order to assimilate the essential requirements of pandemic and move towards a new normal way of life and business. Freedom of movement is considered in these days as more of a curse than bliss! However, a sudden change is unwelcome and causes tumult in human behaviour, preferences and in societies, even in relationships nationally and internationally. Safest place in pandemic times is home; the nest where one finds rest and restoration. However, this notion is being undermined as days pass by with longer imposed containment. The intolerable issues of confinement affect human beings at all levels of body, mind and spirit. Fragile human nature is at stake during long-term indoors; within walls and hot roof, or in chilling cold outside! Walls and roof pose induce ill-effects of confinement and irritation; not just protection and shelter per say. Long-term containment has detrimental effects on people with chronic diseases and ailments. Alcoholics are driven to madness and irresponsible behaviour. Even so-called normal humans display oddities in behaviour; intolerance or lowered tolerance levels, leading families to wreck. It is high time to identify the problems, causes, human preferences and cure in terms of space design that would facilitate people to reach the new normalcy especially in the wake of falling economy. The study analyses the effects of long-term containment on human behaviour, preferences, emotions and changes required in residential spaces. Methodology used is literature survey, observation of community behaviour through digital mediums, and online questionnaire survey of 280 people from various walks of life. This study will help designers all over the globe in the inevitable effort to reach the new normalcy.

\section{Introduction}

Global events of pandemic have struck the world to standstill even before COVID-19. Its adverse effects are affecting normal life; particularly the way societies used to function and relate to one another, spatial order, and normal business. Long-term containment, with its adverse effects on human behaviour is nothing less than the dwindling world economy. These ill-effects are reflected more in terms of spatial order, spatial standards, housing, and rehabilitation later; to reach a new normalcy and day to day business in all walks of life. It calls for challenges and changes in social and individual's behaviour in order to assimilate the essential requirements of pandemic and move towards a new normal. Freedom of movement allowed as a fundamental right is more of a curse than bliss now! However, a sudden change is unwelcome and causes tumult in human behaviour, preferences and in societies, even in relationships nationally and internationally. Safest place considered in pandemic times is home; the nest where one finds rest and restoration. However, this notion is being undermined as days pass by with longer imposed containment. The intolerable issues of confinement affect human beings at all levels of body, mind and spirit. Fragile human nature is at stake indoors; within walls and 
hot roof, or in chilling cold outside! Walls and roof pose also induce ill-effects of confinement and irritation; not just protection and shelter per say. Long-term containment has detrimental effects on people with chronic diseases and ailments. More to say, the elderly with restricted abilities tend to depend on others which causes increased problems and friction within household. Change which is the essence of happy life is at stake, paving way for instability for all; especially children and teen aged. Care and concern in normal human life gets misty and complicated turning social, family and individual lives to doldrums.

Containment is 'the act of restricting free movement of citizens for limiting the spread of something harmful elements like pathogens and carriers.' Due to the outbreak of COVID-19, it has become quite normal to have restrictions imposed through 'containment area' or 'containment zone' as prescribed by appropriate governmental bodies or by the respective governments themselves, restricting the free movement normally allowed to its citizens. This has led to an 'emergency-like' situation in which all normal activities, movements and business are suspended for a period as deemed fit. Further, legal actions are taken against anyone who breaks the restrictions or do not comply with the governmental orders. In such abnormal circumstances, one must spend $90 \%$, if not full time confined to indoors. The idea of buildings to act as a containment spaces have sprig up in order to use such spaces as prime means to combat infectious diseases from reaching 'social spread level'. Many a time reasons for containment are humanitarian emergencies and to prevent societal level spread of pathogens. Such emergencies that societies suffer are natural and environmental emergencies, human-induced emergencies, climate crises, medical and health emergencies which include epidemic or pandemic. Disease outbreak has always prompted innovations in architecture and urban planning over the course of history. A critical study of many major epidemics/pandemics in the last one hundred years revel this fact as follows:

a) 1918-1920 Spanish Flu (H1N1), which infected around 500 million people worldwide and resulted in approximately 50 million deaths.

b) 1957-1958 Asian Flu (H2N2), which resulted in approximately 1.1 million deaths.

c) 1968 Hong Kong Flu (H3N2), which resulted in approximately 1 million deaths.

d) 2002-2003 SARS epidemic confirmed 8096 cases and 774 deaths.

e) 2009-2010 Swine Flu (H1N1), which infected between 700 million and 1.4 billion and resulted in around 201,200 deaths.

f) 2012 MERS-CoV epidemic.

g) 2013 Ebola epidemic.

\section{h) 2019 COVID-19 death tolls are increasing day by day.}

An epidemic is defined as "the occurrence in a community or region of cases of an illness clearly in excess of normal expectancy". However, pandemic is defined as "an epidemic occurring over a vast area, crossing international boundaries, and usually affecting a large number of people" [1]. World Health Organisation (WHO) announced the outbreak of Novel Corona virus Disease (COVID-19) a pandemic on March 11,2020.WHO reiterated its call for countries to take urgent action and accelerate response to trace, diagnose, treat, and reduce its spread to save the lives of people everywhere [2]. Many states have vigorously stepped up intervention steps in terms of identifying, isolating, testing, treating, and tracking potential carriers. The pandemic is relentlessly preying on social cities where freedom of movement is not curbed. The urgent call for social isolation and social distancing are not paid any serious heed by the citizens, which arises further concern. Moreover, it runs counter to human fundamental desire for connection, and socialization for which the cities and plazas, subways and skyscrapers are designed. Increased urban density is the target of many urban environments to work properly and economically sustainable [3]. However, COVID-19 is highly contagious which requires social distancing and long-term containment is the solution to flatten the toll graph until the vaccine is developed. Many countries have imposed lockdown to prevent the spread of this disease. India is not different and the state of Kerala has strictly imposed such measures using law enforcing agencies and medical department.

Although the safest place considered for anyone is their home during the pandemic, the big question is 'Are homes designed for long term containment?' Earlier the notion is that architects and planners have no major role to play in health crises such as pandemics, since they are a matter of medical concern. Even so, now architects, designers and planners are compelled to rethink, about the strategies and tactics to be developed to pave the way for a new normalcy. As the very notion of democracy and free movement are questioned in the wake of long-term containment and social distancing, it is of vital importance to take cognizance of the human requirements in terms of spaces, treatments, technology and other psychological requirements that keep people comfortably contained. A critical study and development of longterm solutions are of highest importance, particularly when the possibility for reoccurrence of such pandemic is not insignificant. World is threatened, so too the existence of human species, in peace and wellbeing!

\section{The Problem}

In the present scenario, societies and humans are deprived of community connections that one normally relies on and enable them to hope, heal, recover, and proceed in life with renewed vigour. However, in the time of pandemic, separation and isolation has become a norm especially in the wake of prolonged durations 
in stages. What humans do normally is the opposite of what they are forced to do in terms of response to major emergencies. 'Social distancing' has quickly become a way of life for most of the inhabitants of the green planet. Although naming physical distancing 'social', it has only contributed to being unsocial. Lack of tolerance, irritability, boredom and increased stress levels make people under long-term containment more of unsocial! Seeing, feeling, listening to one another, interacting in various ways has no place in pandemic situation. During this challenging time, designers, architects and planners shall do everything possible to preserve and foster social lives and wellbeing and comfort of those humans under containment. More so, social distancing is a spatial condition and shall be fought back with appropriate spatial standards, designs, technologies and techniques. This is possible by way of taking stock of the situation and getting to know through surveys what people go through, their preferences, frustrations and other concerns. One must bear in mind that in this time of pandemic, economy dwindles globally, income reduces, prices for commodities skyrocket, lowered affordability and non-availability of labourers or operators and service providers. Considering these limitations alongside, the remedial measures shall be thought of, if it is to be practical.

\section{Research Questions:}

a. What are the effects of long-term containment on human behaviour?

b. Changing human preferences; physical and psychological, emotional and changes required in residential spaces?

c. How do residents respond to long-term social isolation in times of concerns, anxiety and stress?

d. Are the residential spaces available, foster comfort and wellbeing in long-term containment? e. How to modify and augment existing spaces to foster human comfort and wellbeing?

f. How shall architects respond to pandemic situation of a global nature and develop new standards and appropriate design solutions?

\section{Methodology}

The methodology adopted takes the process through published data and articles that have appeared in recent months in various sources; both digital and in print. Further, it involves a large online survey conducted to find out the effects of long-term containment on human behaviour, their preferences, emotions and changes required in residential spaces to foster comfort and wellbeing. Observing the community behaviour and response through various digital means, explore and propose appropriate architectural ideas that would lead to mitigation of ill effects of long-term containment. The people; $(n=280)$ identified for the research are drawn at random, consisting of a representative mix of 145 male and 135 females from all walks of life.; professionals, health workers, employees and students

Age Group, Education qualification and Type of residence of the people participated in online survey are given below. Respondents are from mix group of people staying in urban areas from different states of India. Age group of the respondents are divided in four categories namely 13 years to 19 years (3\%), 19 years to 45 years (74\%), 45 years to 60 years (21\%) and 60 years to 75 years (2\%) (Fig 1.1). Educational qualification of the surveyed varies from Baccalaureate (9\%), Graduates (39\%), Postgraduates (36\%) and above Postgraduates (16\%). (Figure 1) Out of 280 respondents, $19 \%$ respondents stay in single rooms, $51 \%$ respondents stay in Apartments, 30\% respondents stay in Independent houses (Figure 1).

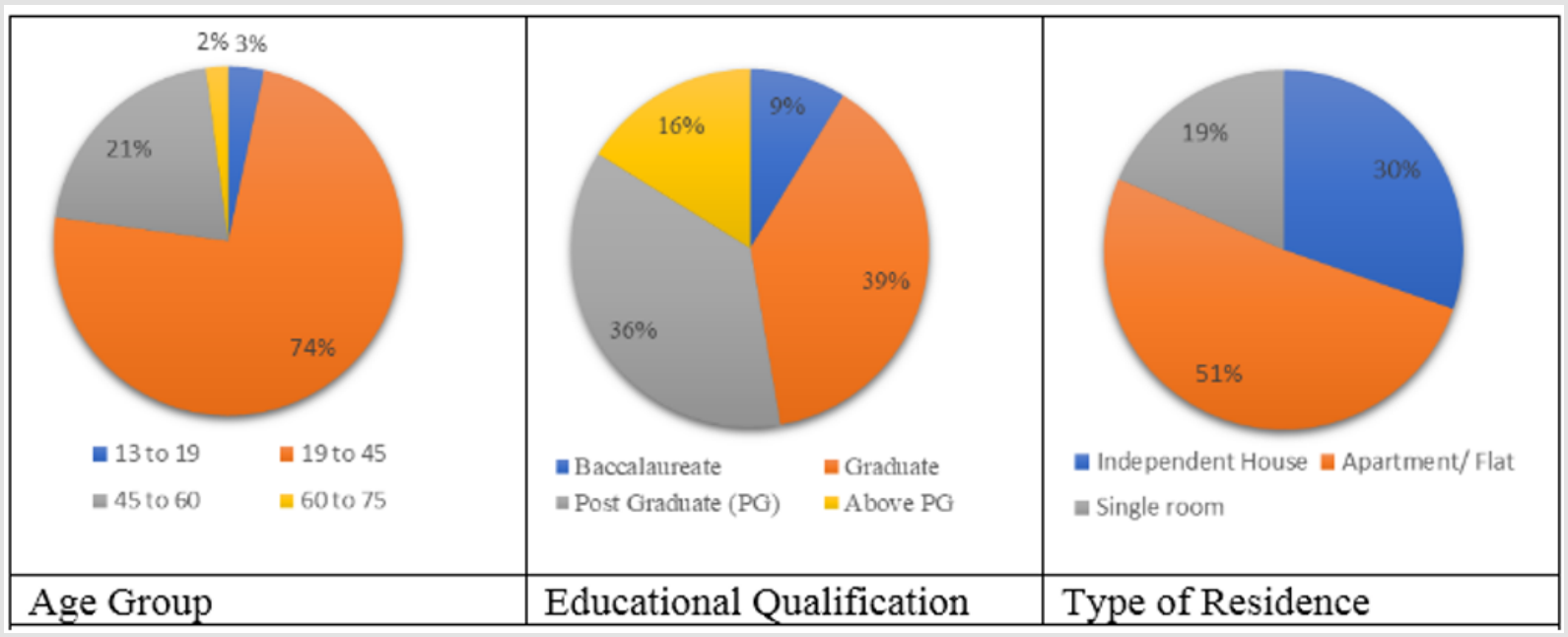

Figure 1: Age-Group, Educational Qualification and Type of Residence. 


\section{Family System}

Most people live in nuclear family either it in apartment or Independent house; 83\% from Apartment and 66\% from Independent house people surveyed live in nuclear family (Figure 2 ), which is the natural response to the growing urbanised world. It is interesting to note that most of all those stay in apartments and single rooms are without extended joint family. This is due to the compulsion of urbanization and its consequences on the family structure to shrink from joint-family to nuclear families; whereas in independent houses and row houses joint-family structure predominates; $34 \%$ people from Independent house stay in joint family whereas as against $17 \%$ people from apartments stay in joint family (Figure 3). One reason for the predominance of extended family in independent houses is to bring down the cost of living to affordable levels by sharing spaces. In a way, this sharing of spaces also contributes to increased density of urban spaces which may facilitate the community spread in terms of pandemic. On the contrary, if it is separate rooms with shared accommodation for different people, to an extent spread of pandemic may be slowed down through shifting of rooms. However, in such a case, all bedrooms shall have attached toilets, and pre-entry spaces that are mandatory in times of pandemic.

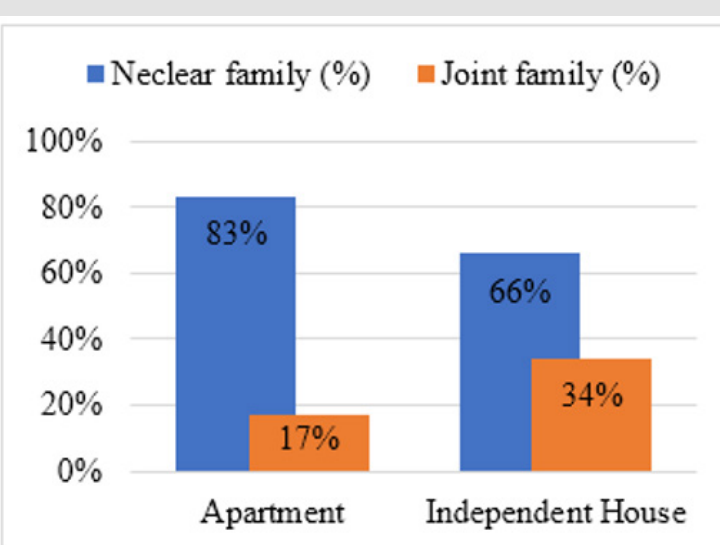

Figure 2: Family System of Apartment and Independent house.

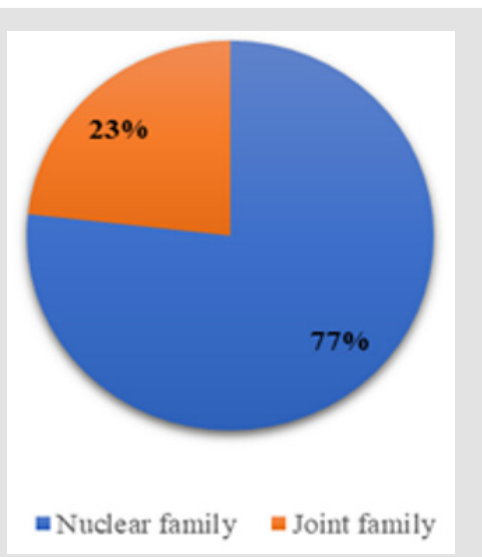

Figure 3: Family System of overall houses.

\section{Residential Space}

In Apartments, 52\% are 2 Bedroom, Hall, \& Kitchen (BHK), 32\% are 3 Bedroom, Hall, \& Kitchen (BHK), 13\% are Single Bedroom, Hall \& Kitchen (BHK) and 3\% are 4 Bedroom, Hall, \& Kitchen (BHK) (Figure 4). In Independent Houses, 33\% are 3 Bedroom, Hall, \& Kitchen (BHK), 28\% are 4 Bedroom, Hall, \& Kitchen (BHK), 24\% are 2 Bedroom, Hall, \& Kitchen (BHK), 12\% are 5 Bedroom, Hall, \&Kitchen and more), ????? \% are (Single Bedroom, Hall, \&Kitchen) (Figure 4). It is evident from the studies that most of the housing stock surveyed consists of 1, 2 and 3 BHK units where the subjects surveyed live under space restrictions. In such a case the numbers of toilet attached bedrooms are only two, except single room category. Therefore, it can be observed that these housing stocks cannot accommodate social distancing or isolation as required in a pandemic like COVID-19. Further, these housing stocks cannot be modified to suit the pandemic requirements even with difficulty, except most essential interior modifications as per the preference of the residents. It is most important to take care of the additional space requirements by way of creative designs that allow regrouping of internal spaces with flexibility. One of such thinking for new constructions is to 'choose long span free spaces' with dismountable internal structures which are mostly of prefabricated and manufactured boards and framework. Such flexible spaces with prefabricated internal partitions facilitate the regrouping and redesign for changing pandemic spatial requirements. Since such large-span structures facilitate flexibility, and the resulting housing will be much more acceptable and remain sustainable in the long run.

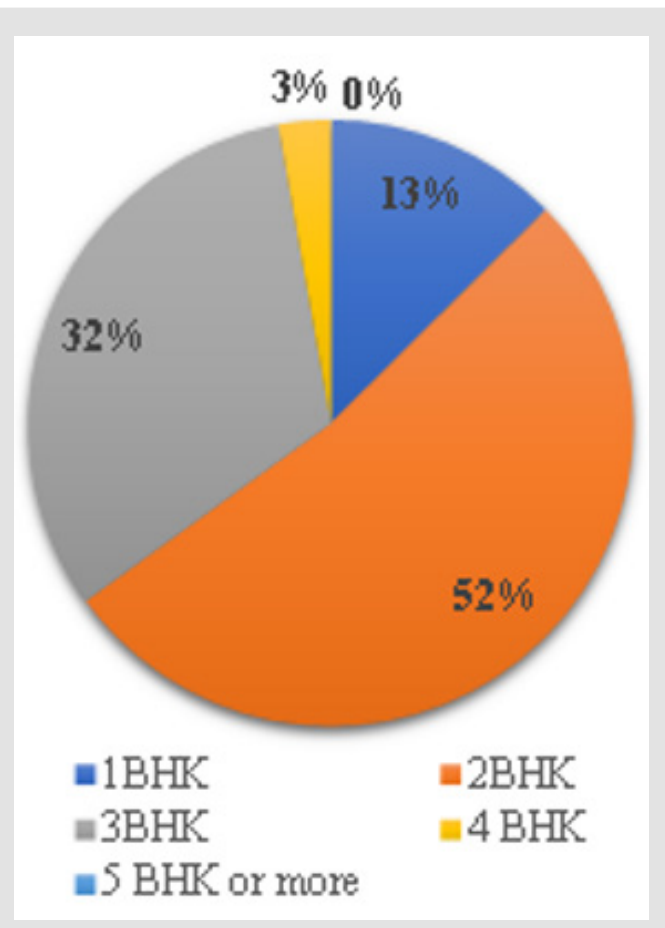

Figure 4: Number of Rooms (in terms of percentage) in Apartment. 


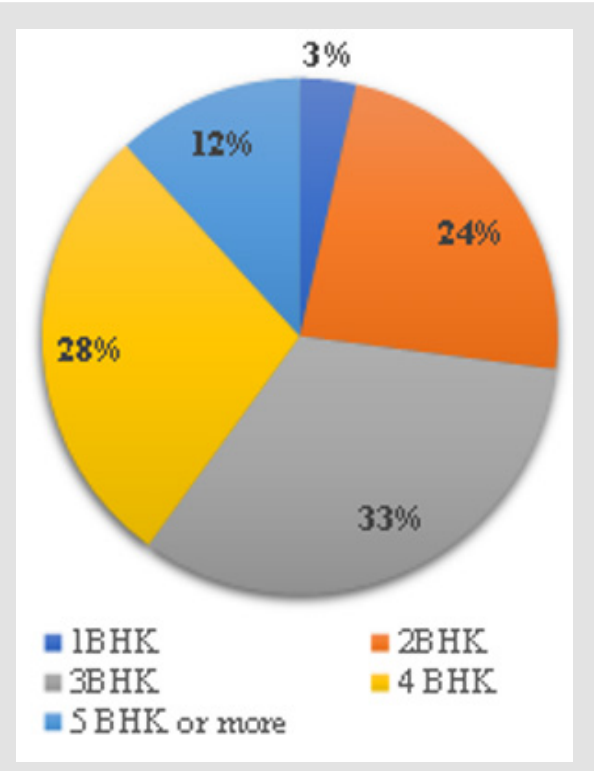

Figure 5: Number of Rooms (in terms of percentage) Independent house.

\section{Effects of Pandemic on Emotional Wellbeing}

Developmentalists often categorize the human lifespan into Prenatal Development + Infancy and Toddlerhood (0 to 2 years), Early Childhood (2 to 6 years), Middle Childhood (6 to 11 years), Adolescence (12 to 18 years), Early Adulthood (20 to 40 years), Middle Adulthood (40 to 65 years), Late Adulthood (65 to 74 years). [4] The problems associated with each category also are different, since the needs, abilities and preferences vary. While elderly are facing the challenges of lowered physical and mental abilities which require special standards and assistance, adolescence have extra energy, need for peer companies and group activities, living outdoors and games etc. whereas, 'Early Adulthood' and 'Middle Adulthood' people are the bread-winners in any typical family. They are therefore, required to work from home which requires 'long sitting' and 'acceptable workspaces' at home. The Middle Adulthood has the extra problems relating to growing age like medical, physical and psychological. On the contrary, Children, when confined to closed spaces for prolonged periods, tend to be physically less active, develop irregular sleep patterns, have less favourable diets, leading to unhealthy weight gain and even a loss of cardiorespiratory fitness [5].

Presence of outdoor elements such as plants, water, bird sounds, sunlight and wind give the feel of outdoors inside, which enables the residents in all age-groups to remain happy and comfortable. Architects are compelled to explore the possibly in achieving the presence of outdoor elements in new as well as existing indoors in enabling the residents of housing to stay happily and comfortably in long-term containment spaces. Pandemic also lead to less of outdoor activity, and interaction with peer group gets restricted. [6] Studies show that the mean traumatic stress scores of children quarantined are four times compared to those who are not quarantined. Lack of social support due to isolation may lead to poor compliance, depression, ill-being and increased stress. [7] The problem of increased stress and lowered tolerance level is applicable to all groups of people; particularly to 'Early Adulthood' and 'Middle Adulthood 'people. These two reasons when combined with the lowered income during a pandemic lockdown period, catalyzes the incidence and probability of incidence for domestic violence. It is of no wonder that United Nations have reported a 'horrifying global surge in domestic violence' during the COVID-19 [8] and aging population may experience increased physical limitations or psychological challenges. One important cause to such an unhealthy state is increased stress, irritability and growing impatience in the contained. Architects have a great role to play in identifying the reasons for such behaviour; particularly from environmental and spatial points of view and create remedial solutions to lower or negate such problems.

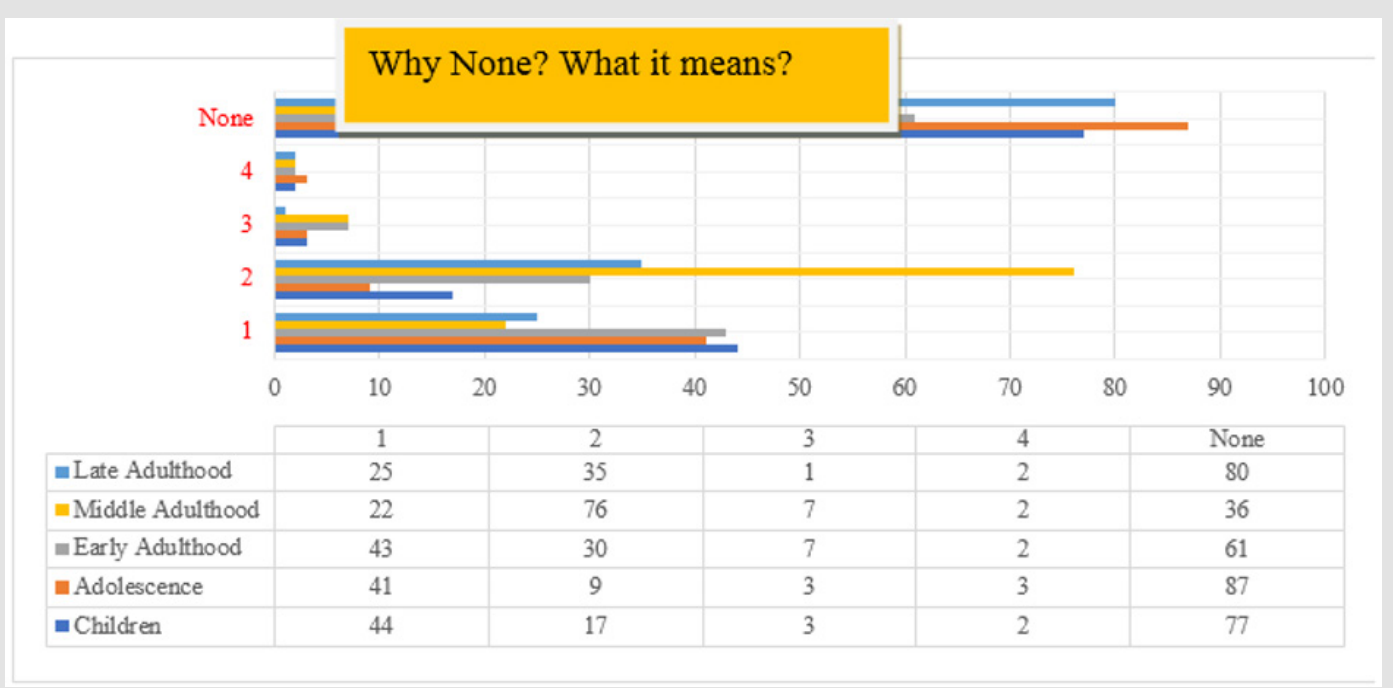

Figure 6: Categorisation of human life span in Apartments. 
In India, joint family system has prevailed from the Vedic times and joint families still prevail in better state of health with high values and morale, as compared to the nuclear families that has lost brakes and cushions. The survey reveals that people who are staying in joint family has many advantages over nuclear family especially with mutual support in respect to growing children, the breadwinners; working people from home, and elderly. This benefit is from mutual care, concern, affection and increased family support. The study reveals that respondents from joint family are more personally, interpersonally and socially satisfied in the current stage of pandemic in comparison to those from nuclear family. In the case of nuclear families opting for 'work from home'; daily chores and taking care of children is burdensome; particularly to women, as compared to joint families where children are mostly engaged with their grandparents. The positive support from elders facilitates the breadwinners to concentrate on their office work and home chores although it depends much on the inter-relations of family members. Moreover, the mixing of children with elderly benefit both to stay indoors happily and emotionally connected reducing stress levels, although it must be done with care to prevent mixing since elderly are more vulnerable.

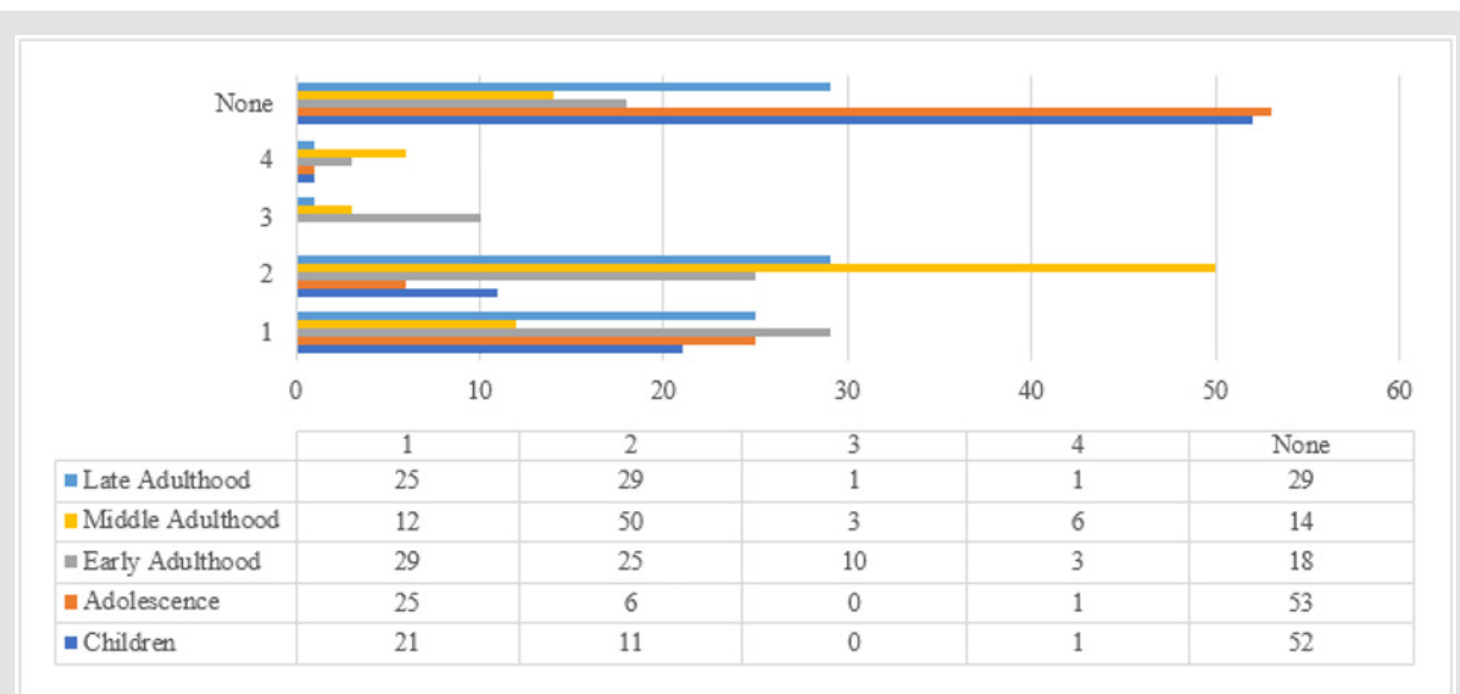

Figure 7: Categorisation of human life span in Independent house.

\section{Effects of Long-Term Containment on Human Behaviour}

The surveyed are asked to mark their opinion regarding important problems faced by them pandemic period. The responses are marked on a 5-point Likert Scale. Furtherer, this survey has been performed on three basic levels namely 'Single Room', 'Apartment' and 'Independent house'. The results are shown in the following Tables. (Table No. ?????). It is quite understandable that the problems reported by those staying in Single Room are Discomfort from long sitting, Desire for friendship and meeting other people, Lack of entertainment/engagement which finally lead to Boredom. Lack of extra space due to economic considerations must be creatively dealt with in this category of residential spaces.

Table 1: Effects of long-term containment on human behaviour residing in single room.

\begin{tabular}{|c|c|c|c|c|c|c|c|c|}
\hline \multirow{2}{*}{ Sr. No. } & \multirow{2}{*}{ Problem: } & 1 & 2 & 3 & 4 & 5 & \multirow{2}{*}{ Total } & \multirow{2}{*}{$\begin{array}{c}\text { Mean of } \\
\text { Responses (M) }\end{array}$} \\
\hline & & Never & Rarely & Occasionally & Often & Always & & \\
\hline 1 & Stress/psychological problems & 1 & 12 & 12 & 8 & 0 & 33 & 2.5 \\
\hline 2 & Discomfort from long sitting & 0 & 6 & 21 & 8 & 5 & 40 & 3.1 \\
\hline 3 & Desire for friendship & 0 & 6 & 15 & 12 & 10 & 39 & 3.3 \\
\hline 4 & Meeting people & 0 & 4 & 18 & 12 & 10 & 44 & 3.4 \\
\hline 5 & Confinement and lack of interest & 1 & 12 & 6 & 12 & 5 & 36 & 2.8 \\
\hline
\end{tabular}




\begin{tabular}{|c|c|c|c|c|c|c|c|c|}
\hline 6 & $\begin{array}{c}\text { Lack of entertainment/ } \\
\text { engagement }\end{array}$ & 1 & 6 & 12 & 20 & 0 & 39 & 3.0 \\
\hline 7 & Lack of landscape interiors & 2 & 8 & 12 & 12 & 0 & 34 & 2.6 \\
\hline 8 & Boredom & 1 & 6 & 12 & 8 & 15 & 42 & 3.2 \\
\hline
\end{tabular}

Notes: Each item is measured on a 5-point Likert scale, $M$ scores 3 and above 3 implies problems exist; these are of the participants who reported either 4 or 5 .

Itis observed from the survey conducted thatapartment dwellers are basically nuclear families. Their desire for socialization and friendships are essentially satisfied by visiting friends and families most often weekly. This is an essential fact which also enables them to live stress-free and supported mutually in urban life. Discomfort from long sitting, lack of outdoor elements and boredom are the major problems faced by apartment dwellers. This too could be creatively resolved with large-span structures, long ventilated and lit corridors separating internal spaces and introduction of outdoor elements, inside. Careful and creative minds of architects could think of introducing even life on walls like aquariums, green micro landscapes etc. to prevent boredom indoors and facilitate happy long-term containment. (Table 2) Problems observed in Independent house category are much like that of apartment dwellers, although they have the advantage of more internal space and outdoor spaces in specific cases. Considering the situation, the suggestions given in the case of apartments are applicable to this category too, effectively. One design prescription seems good is to follow simple and isolatable spatial grids, with open to sky courtyard in design. It is important to note that complexity in space design is opposed to flexibility and resulting sustainability (Table $3)$.

Table 2: Effects of long-term containment on human behaviour residing in Apartment.

\begin{tabular}{|c|c|c|c|c|c|c|c|c|}
\hline \multirow{2}{*}{ Sr. No. } & Problem: & $\mathbf{1}$ & $\mathbf{2}$ & $\mathbf{3}$ & $\mathbf{4}$ & $\mathbf{5}$ & \multirow{2}{*}{$\begin{array}{c}\text { Tetal } \\
\text { Rean of }\end{array}$} \\
\cline { 3 - 8 } & & Never & Rarely & Occasionally & Often & Always & & 294 \\
\hline 1 & Stress/psychological problems & 58 & 70 & 108 & 48 & 10 & 2.06 \\
\hline 2 & Discomfort from long sitting & 34 & 74 & 123 & 100 & 30 & 361 & 2.52 \\
\hline 3 & Desire for friendship & 30 & 46 & 144 & 80 & 110 & 410 & 2.87 \\
\hline 4 & Meeting people & 17 & 58 & 138 & 116 & 110 & 439 & 3.07 \\
\hline 5 & Confinement and lack of interest & 41 & 80 & 99 & 108 & 10 & 338 & 2.36 \\
\hline 6 & $\begin{array}{c}\text { Lack of entertainment/ } \\
\text { engagement }\end{array}$ & 50 & 72 & 96 & 76 & 30 & 324 & 2.27 \\
\hline 7 & Lack of landscape interiors & 45 & 50 & 78 & 92 & 120 & 385 & 2.69 \\
\hline 8 & Boredom & 38 & 76 & 111 & 84 & 45 & 354 & 2.48 \\
\hline
\end{tabular}

Notes: Each item is measured on a 5-point Likert scale, M scores 3 and above 3 implies problems exist; these are of the participants who reported either 4 or 5 .

Table 3: Effects of long-term containment on human behaviour residing in Independent house.

\begin{tabular}{|c|c|c|c|c|c|c|c|c|}
\hline \multirow{2}{*}{ Sr. No. } & \multirow{2}{*}{ Problem: } & 1 & 2 & 3 & 4 & 5 & \multirow{2}{*}{ Total } & \multirow{2}{*}{$\begin{array}{c}\text { Mean of } \\
\text { Responses (M) }\end{array}$} \\
\hline & & Never & Rarely & Occasionally & Often & Always & & \\
\hline 1 & Stress/psychological problems & 88 & 79 & 61 & 21 & 4 & 253 & 2.98 \\
\hline 2 & Discomfort from long sitting & 66 & 66 & 60 & 51 & 10 & 253 & 2.98 \\
\hline 3 & Desire for friendship & 55 & 45 & 79 & 41 & 33 & 253 & 2.98 \\
\hline 4 & Meeting people & 34 & 50 & 84 & 45 & 43 & 256 & 3.01 \\
\hline 5 & Confinement and lack of interest & 66 & 77 & 53 & 52 & 7 & 255 & 3.00 \\
\hline 6 & $\begin{array}{c}\text { Lack of entertainment/ } \\
\text { engagement }\end{array}$ & 84 & 64 & 48 & 46 & 9 & 251 & 2.95 \\
\hline 7 & Lack of landscape in interiors & 81 & 51 & 47 & 38 & 33 & 250 & 2.94 \\
\hline 8 & Boredom & 66 & 60 & 65 & 39 & 26 & 256 & 3.01 \\
\hline
\end{tabular}

Notes: Each item is measured on a 5-point Likert scale, M scores 3 and above 3 implies problems exist; these are of the participants who reported either 4 or 5 . 


\section{Long-term Containment and Residential Space}

In the current situation of pandemic, architects and planners are compelled to reconsider their roles and responsibilities, since the outbreak of COVID-19 that has taken a heavy toll on human lives over the globe. The situation is quite alarming with the doubling of 'infected cases' in every 12-14 days. Architecture is an essential product of society that manifests the concerns and considerations of people and their group wisdom. However, the concept of society itself is founded in interactions and togetherness. This very foundation is shaken when the requirement to deal effectively with the pandemic is 'social distancing' and 'isolation'. During the Second World War, when the human toll of war was horrific, leaving many cities and economies in shambles, architects were able to direct the new rebuilding of destroyed cities towards more just, fair, and prosperous societies. This was facilitated by standardisation and mass production which require 'less is more' and the resulting simplicity. In this pandemic time, architects shall have to learn a lesson from 'less is more and straightforward planning', especially in the design of residential spaces. Their first concern shall be, to help the world battle the raging deadly pandemic, and then to help communities recover and rebuild, implementing lessons that can hopefully avoid future health and environmental disasters $[9,10]$. In a way, restoration and retrofit of existing stock of housing shall be of priority as revealed through the survey findings.

Although architecture has multi-perspective parameters or design concerns; Aesthetic (timelessness), Socio-cultural (appropriateness), Environmental (resource management), Economic (affordability), Structural (strength and stability); none of these is primary to saving lives and achieving wellbeing in the pandemic situation. It is, therefore, a creative challenge to transform the calamity in to a 'prospective project' that facilitates the healthy coexistence of societies and world at large. How will be a new normal be? Shall it shrink further the already shrunk humans in the world and confine them to virtual reality? Is it not architect's responsibility to foster a healthy and civilized human existence in the green globe? Staying indoors in home, although is the safest place right now, does this foster a healthy society in future? Staying at home and working from home will reduce travel time and has environmental benefits like reduced greenhouse gas emissions, decreased consumption of fossil fuels, lessened impact on infrastructure. Are these all not going against the basic free travel and resulting human interactions? Already people are getting polarised, generating further unrest and tension all over the globe. Healthy and creative intervention and designs are unavoidable these days. To analyse how pandemic will impact residential spaces in terms of physical spatial elements; 'floor, column, wall, fenestrations, stair, ceiling/roof' and natural elements; 'sun, wind, water, vegetation, landform, people and activity' the survey addressed these concerns.

Qn. 1: The first question addressed the need for additional spaces like open area/ balcony/ terrace, in various categories. The responses are given below in (Table....??????)

Single Room: Respondents staying in the single room are the residents of institutional housing like hostels. 54\% respondents stay in rooms having carpet area of 80 sq. ft. to 100 sq. $\mathrm{ft}$. $46 \%$ respondents stay in the room having area of $100 \mathrm{sq}$. $\mathrm{ft}$. to $150 \mathrm{sq}$. $\mathrm{ft}$. $77 \%$ respondents have single occupancy, $16 \%$ have double occupancy, 7\% have four persons/room occupancy in hostels. $100 \%$ respondents have open outdoor area attached to their rooms but spatial elements and activities their responses are as follows (Table 4). Thanks to the lockdown imposed, respondents are unable to go to gyms, or take part in sports or social gathering. Regarding spatial elements and activities, respondents would like to add on priority basis 'Gardening, Place for exercise, Courtyard and Indoor landscaping'. However, on individual basis these suggestions are not economically viable [11-16]. The alternatives are to give feasible and 'isolatable blocks' with common amenities 'roof top gardens' or even 'vertical farming'. Potential gardening systems with integrated drip irrigation are already available in the market. Once such creative and healthy solutions are integrated with institutional housing it is possible to ameliorate the boredom and stress build-up in the occupants. Further, they also may be provided with 'art and craft spaces' where they could engage their minds creatively. These suggestions shall be better feasible in new constructions and incentives will be beneficial to those who take part in terrace farming.

Table 4: Effects of long-term containment on residential area in single room.

\begin{tabular}{|c|c|c|c|c|c|c|c|c|c|}
\hline \multirow[b]{2}{*}{ Additional Spaces } & 1 & 2 & 3 & 4 & 5 & 6 & 7 & \multirow[b]{2}{*}{ Total } & \multirow{2}{*}{$\begin{array}{l}\text { Mean of } \\
\text { Responses } \\
\text { (M) }\end{array}$} \\
\hline & $\begin{array}{c}\text { Not a } \\
\text { priority }\end{array}$ & $\begin{array}{c}\text { Low } \\
\text { Priority }\end{array}$ & $\begin{array}{c}\text { Somewhat } \\
\text { Priority }\end{array}$ & Neutral & $\begin{array}{l}\text { Moderate } \\
\text { Priority }\end{array}$ & $\begin{array}{c}\text { Moderate } \\
\text { Priority }\end{array}$ & $\begin{array}{c}\text { Essential } \\
\text { Priority }\end{array}$ & & \\
\hline Gardening & 1 & 2 & 3 & 8 & 0 & 24 & 28 & 66 & 5.08 \\
\hline Place for exercise & 3 & 0 & 0 & 0 & 0 & 36 & 28 & 67 & 5.15 \\
\hline Coffee table & 3 & 4 & 3 & 0 & 10 & 18 & 14 & 52 & 4.00 \\
\hline Courtyard & 2 & 2 & 0 & 0 & 10 & 12 & 42 & 68 & 5.23 \\
\hline Indoor landscaping & 0 & 2 & 3 & 0 & 25 & 18 & 21 & 69 & 5.31 \\
\hline
\end{tabular}

Note: Each item is measured on a 7-point Likert scale, $\mathrm{M}$ above 4 implies spaces participants would like to add on priority basis in open area/ balcony/ terrace; these are of the participants who reported either 5, 6 or 7 . 
Apartments: Respondents for this study are either from urban or semi-urban areas spread across India, and random in selection. These respondents have begun working from home as permitted during lockdown period, till relaxations are declared by the concerned governments. Of these, $83 \%$ belong to nuclear family, $17 \%$ belong to joint family. Although $84 \%$ respondents have access to open area in terms of balcony, terrace and $16 \%$ respondents do not have access to open area attached to their apartment; all of them are working from home. The spatial elements and activities they would like to add in their open areas are given in Table 5. Such spatial elements and activities the respondents would like to add on priority basis are Gardening, Place for exercise, and Indoor landscaping. Majority of such preferences are emanating from the human need to be in the outdoors with rich landscapes, consisting of flora and fauna. Vertical landscaping, vertical farming, crafts and creative spaces; if carefully added in well integrated manner, will provide a panacea for such a situation. Further, governments shall prescribe 'incentives and necessary byelaws' in achieving these targets. Every rooftop in such a case shall turnout to be agricultural production areas at the location of consumption itself. Every household can actively participate in such positive initiatives and lessen the burden of heat load on buildings, $\mathrm{CO}_{2}$ emissions from transportation. It could be seen that ' $\mathrm{H}$ ', ' $\mathrm{X}$ ', and ' $Y$ ' shaped residential blocks with large spans will be conducive to make isolatable blocks with flexible internal spaces built up from dismountable, manufactured panels for effective partition.

Table 5: Effects of long-term containment on residential area in Apartment.

\begin{tabular}{|c|c|c|c|c|c|c|c|c|c|}
\hline \multirow[b]{2}{*}{ Additional Spaces } & 1 & 2 & 3 & 4 & 5 & 6 & 7 & \multirow[b]{2}{*}{ Total } & \multirow{2}{*}{$\begin{array}{c}\text { Mean of } \\
\text { Responses } \\
\text { (M) }\end{array}$} \\
\hline & $\begin{array}{c}\text { Not a } \\
\text { priority }\end{array}$ & $\begin{array}{c}\text { Low } \\
\text { Priority }\end{array}$ & $\begin{array}{c}\text { Somewhat } \\
\text { Priority }\end{array}$ & Neutral & $\begin{array}{c}\text { Moderate } \\
\text { Priority }\end{array}$ & $\begin{array}{c}\text { High } \\
\text { Priority }\end{array}$ & $\begin{array}{c}\text { Essential } \\
\text { Priority }\end{array}$ & & \\
\hline Gardening & 11 & 16 & 87 & 48 & 115 & 228 & 154 & 659 & 4.61 \\
\hline Place for exercise & 13 & 18 & 60 & 52 & 145 & 222 & 154 & 664 & 4.64 \\
\hline Coffee table & 24 & 28 & 60 & 108 & 130 & 132 & 70 & 552 & 3.86 \\
\hline Courtyard & 29 & 44 & 39 & 96 & 115 & 84 & 126 & 533 & 3.73 \\
\hline Indoor landscaping & 17 & 38 & 63 & 56 & 145 & 168 & 105 & 592 & 4.14 \\
\hline
\end{tabular}

Note: Each item is measured on a 7-point scale, M scores 4 and above 4 implies spaces participants would like to add in open area/ balcony/ terrace; these are of the participants who reported either 5, 6 or 7 .

Independent House: It could be observed from the survey results that most of the Independent and Row houses open to a separate lobby, courtyard, or living room. It is a healthy practice in traditional houses to provide a separate area for washing hands, face and feet before entering the house. Fresh water is kept in appropriate utensils for such use. It may be due to space constraints and low affordability that these essential 'pre-entry, transition areas' have vanished from so called modern residential designs. However, the fact is that $99 \%$ respondents would prefer to have these healthy transition spaces; especially in pandemic times. Making it a norm would help in creating necessary cleanliness indoors. These transition areas can be used for keeping shoes and other articles that one uses outdoors effectively separated from indoors; using air-curtains, proper lighting and ventilation [17-20].

Although 94\% respondents have open area attached to house, these are not used creatively and economically viable manner. However, 6\% do not have an open area attached to house. Regarding community with common gathering and recreational space, $79 \%$ responded "yes" and 21\% responded "no". Such community spaces are not advisable unless they are isolatable and kept sanitised.
However, 58\% responded "no" and 42\% responded "yes" to office spaces to be provided in residential places. Additional office spaces will be an advantage, especially when it comes to necessary 'work from home' situation, if allowed. Although 65\% respondents preferred 'work from home' even in post-pandemic period, if the new normal dictates it, they would prefer to have 'separate office space' in residential spaces. If not, being a family with small children, it is hard to concentrate and be productive in 'work from home', since effective working requires segregation and privacy. Moreover, 35\% respondents prefer not to 'work from office' since it provides direct social interactions which is healthy for mind and body (Table 6). Spatial elements and activities, respondents would like to add on priority basis are 'Gardening, Place for exercise, and courtyard'. Especially in pandemic situation, respondents prefer to add Working space/Office Space (44\%), Indoor courtyard with landscape (45\%), Outdoor Seating (50\%), Outdoor Seating with vertical farming (28\%), Balcony with vertical farming (22\%), Balcony without vertical farming (10\%), Green Roof without vertical farming (20\%), Green Roof with vertical farming (30\%), and Place for exercise (62\%). 
Table 6: Effects of long-term containment on residential area in Independent house.

\begin{tabular}{|c|c|c|c|c|c|c|c|c|c|}
\hline \multirow[b]{2}{*}{ Additional Spaces } & 1 & 2 & 3 & 4 & 5 & 6 & 7 & \multirow[b]{2}{*}{ Total } & \multirow{2}{*}{$\begin{array}{l}\text { Mean of } \\
\text { Responses } \\
\text { (M) }\end{array}$} \\
\hline & $\begin{array}{c}\text { Not a } \\
\text { priority }\end{array}$ & $\begin{array}{c}\text { Low } \\
\text { Priority }\end{array}$ & $\begin{array}{c}\text { Somewhat } \\
\text { Priority }\end{array}$ & Neutral & $\begin{array}{l}\text { Moderate } \\
\text { Priority }\end{array}$ & $\begin{array}{c}\text { High } \\
\text { Priority }\end{array}$ & $\begin{array}{c}\text { Essential } \\
\text { Priority }\end{array}$ & & \\
\hline Gardening & 4 & 18 & 36 & 36 & 70 & 108 & 133 & 405 & 4.76 \\
\hline Place for exercise & 8 & 10 & 45 & 56 & 95 & 84 & 70 & 368 & 4.33 \\
\hline Coffee table & 23 & 22 & 24 & 60 & 80 & 42 & 35 & 286 & 3.36 \\
\hline Courtyard & 14 & 16 & 36 & 44 & 70 & 60 & 112 & 352 & 4.14 \\
\hline Indoor landscaping & 13 & 18 & 51 & 68 & 70 & 30 & 70 & 320 & 3.76 \\
\hline
\end{tabular}

Note: Each item is measured on a 7-point scale, M scores 4 and above 4 implies spaces participants would like to add in open area/ balcony/ terrace; these are of the participants who reported either 5, 6 or 7 .

COVID-19 and such pandemic arise questions of designing a residential space for infectious diseases where isolation and social distancing is the major criteria to be considered. Residential areas are quite varied in density and character; they range from leafy suburbs to apartment buildings in the core of cities. Apartments, homes need to provide support, challenge, and delight to maintain physical and mental health. Not all homes are healthy, many add threat to public health and productivity, particularly in dense urban environments: door handles, crowded lifts with buttons to press; residential spaces without sufficient light, poor indoor air quality caused by fungus or poor ventilation, fresh air and greenery, no space for Physical activity which are design issues to be sorted out creatively [21-25].

\section{Qn. 2: What behavioural changes do you suggest that need spatial alteration?}

Table 7: Suggested spatial alteration in Single Room.

\begin{tabular}{|c|c|c|c|c|c|c|c|c|c|}
\hline \multirow[b]{2}{*}{ Spatial Alteration } & 1 & 2 & 3 & 4 & 5 & 6 & 7 & \multirow[b]{2}{*}{ Total } & \multirow{2}{*}{$\begin{array}{l}\text { Mean of } \\
\text { Responses } \\
\text { (M) }\end{array}$} \\
\hline & $\begin{array}{c}\text { Not at all } \\
\text { important }\end{array}$ & $\begin{array}{c}\text { Low } \\
\text { importance }\end{array}$ & $\begin{array}{l}\text { Slightly } \\
\text { important }\end{array}$ & Neutral & $\begin{array}{c}\text { Moderately } \\
\text { important }\end{array}$ & $\begin{array}{c}\text { Very } \\
\text { important }\end{array}$ & $\begin{array}{l}\text { Extremely } \\
\text { important }\end{array}$ & & \\
\hline Lighting on floor & 1 & 6 & 12 & 4 & 10 & 6 & 7 & 46 & 3.54 \\
\hline Music as you walk & 3 & 6 & 3 & 0 & 20 & 12 & 0 & 44 & 3.38 \\
\hline Digital walls & 2 & 8 & 3 & 12 & 5 & 12 & 0 & 42 & 3.23 \\
\hline $\begin{array}{c}\text { Life on the walls like } \\
\text { aquarium }\end{array}$ & 2 & 2 & 6 & 0 & 25 & 0 & 21 & 56 & 4.31 \\
\hline Landscape on walls & 2 & 0 & 6 & 8 & 10 & 12 & 21 & 59 & 4.54 \\
\hline $\begin{array}{l}\text { Special colour } \\
\text { schemes }\end{array}$ & 1 & 2 & 6 & 0 & 15 & 24 & 14 & 62 & 4.77 \\
\hline $\begin{array}{l}\text { Larger glazed } \\
\text { window area }\end{array}$ & 1 & 0 & 6 & 0 & 10 & 18 & 35 & 70 & 5.38 \\
\hline
\end{tabular}

Note: Each item is measured on a 7-point scale, M scores 4 and above 4 implies spaces participants' needs spatial alteration; these are of the participants who reported either 5,6 or 7 .

Single Room: It could be deducted from the survey results that what people desire most is openness and freedom which could be compared most to large glazed window area. Such a feel of openness is derived from the 'transparency of glass' and 'fresh air' availability if the windows are open. Thus, it extends the view from the contained spaces to outdoors ameliorating the ill-effects of containment. Secondly, it is seen that people always prefer nature and natural materials over artificial products to be used for surface treatments. This is due to the programmed rhythm in such, which when repeated results in boredom. However, living materials; whether plants or fish, require constant maintenance which is a bliss in containment period as well as botheration in work and normalcy. If careful choices can be made, such a preference will lead to engagement and diversion appropriately. It could also see that people prefer colours as they are influenced by their on mental make-up, associations, and culture. This is however, an easy change that could be achieved appropriately [26-30] (Table 7).

Apartments: The explanations and deductions given in the case of single rooms are valid in the case of Apartments too. The choice of landscape is a matter of constant maintenance and if this could be integrated and automated it is a considerable option in both normalcy and containment period (Table 8). 
Table 8: Suggested spatial alteration in Apartment.

\begin{tabular}{|c|c|c|c|c|c|c|c|c|c|}
\hline \multirow[b]{2}{*}{ Spatial Alteration } & 1 & 2 & 3 & 4 & 5 & 6 & 7 & \multirow[b]{2}{*}{ Total } & \multirow{2}{*}{$\begin{array}{l}\text { Mean of } \\
\text { Responses } \\
\text { (M) }\end{array}$} \\
\hline & $\begin{array}{l}\text { Not at all } \\
\text { important }\end{array}$ & $\begin{array}{c}\text { Low } \\
\text { importance }\end{array}$ & $\begin{array}{l}\text { Slightly } \\
\text { important }\end{array}$ & Neutral & $\begin{array}{l}\text { Moderately } \\
\text { important }\end{array}$ & $\begin{array}{c}\text { Very } \\
\text { important }\end{array}$ & $\begin{array}{l}\text { Extremely } \\
\text { important }\end{array}$ & & \\
\hline Lighting on floor & 43 & 64 & 63 & 40 & 65 & 84 & 70 & 429 & 3.00 \\
\hline Music as you walk & 34 & 44 & 75 & 92 & 110 & 48 & 63 & 466 & 3.26 \\
\hline Digital walls & 46 & 66 & 36 & 96 & 100 & 36 & 14 & 394 & 2.76 \\
\hline $\begin{array}{c}\text { Life on the walls like } \\
\text { aquarium }\end{array}$ & 36 & 64 & 39 & 96 & 130 & 60 & 14 & 439 & 3.07 \\
\hline Landscape on walls & 13 & 36 & 57 & 64 & 180 & 174 & 84 & 608 & 4.25 \\
\hline $\begin{array}{l}\text { Special colour } \\
\text { schemes }\end{array}$ & 13 & 24 & 48 & 72 & 150 & 204 & 140 & 651 & 4.55 \\
\hline $\begin{array}{l}\text { Larger glazed } \\
\text { window area }\end{array}$ & 1 & 22 & 51 & 56 & 105 & 228 & 287 & 750 & 5.24 \\
\hline
\end{tabular}

Note: Each item is measured on a 7-point scale, M scores 4 and above 4 implies spaces participants needs spatial alteration; these are of the participants who reported either 5,6 or 7 .

Independent House: The explanations and deductions given in the case of single rooms is valid in the case of Independent house + Row house too. The choice of landscape is a matter of constant maintenance and if this could be integrated and automated it is a considerable option in both normalcy and containment period. However, since the availability open spaces is there with Independent house + Row house, the choice of additional landscape seems to be bleak (Table 9). If you would like to add pleasant sounds in your home that would be (Table 10). What is the pleasant aroma you have/want in your home? (Table 11) Although the respondent's choices may be appreciated, it must be kept in mind that boredom from repeated odour puffers could lead to irritation which depends on the mood of individuals. Further, the mix of different remnants of odours might lead to something of dislike, since different chemicals may react with one another. Further, aerosols generally are causing problem to lungs and human health. Therefore, it is advisable to go for such incorporations carefully, giving maximum priority to least disturbing and least troublesome, if not harmless choices, that too in mild doze. Moreover, adopt individual choices appropriately with regulating devices [31,32].

Table 9: Suggested spatial alteration in Apartment.

\begin{tabular}{|c|c|c|c|c|c|c|c|c|c|}
\hline \multirow[b]{2}{*}{ Spatial Alteration } & 1 & 2 & 3 & 4 & 5 & 6 & 7 & \multirow[b]{2}{*}{ Total } & \multirow{2}{*}{$\begin{array}{l}\text { Mean of } \\
\text { Responses } \\
\text { (M) }\end{array}$} \\
\hline & $\begin{array}{c}\text { Not at all } \\
\text { important }\end{array}$ & $\begin{array}{c}\text { Low } \\
\text { importance }\end{array}$ & $\begin{array}{l}\text { Slightly } \\
\text { important }\end{array}$ & Neutral & $\begin{array}{l}\text { Moderately } \\
\text { important }\end{array}$ & $\begin{array}{c}\text { Very } \\
\text { important }\end{array}$ & $\begin{array}{l}\text { Extremely } \\
\text { important }\end{array}$ & & \\
\hline Lighting on floor & 32 & 34 & 39 & 36 & 25 & 36 & 21 & 223 & 2.62 \\
\hline Music as you walk & 30 & 32 & 24 & 48 & 65 & 12 & 28 & 239 & 2.81 \\
\hline Digital walls & 31 & 34 & 42 & 40 & 30 & 24 & 21 & 222 & 2.61 \\
\hline $\begin{array}{c}\text { Life on the walls like } \\
\text { aquarium }\end{array}$ & 27 & 36 & 27 & 56 & 30 & 48 & 21 & 245 & 2.88 \\
\hline Landscape on walls & 16 & 26 & 42 & 32 & 85 & 60 & 49 & 310 & 3.65 \\
\hline $\begin{array}{l}\text { Special colour } \\
\text { schemes }\end{array}$ & 13 & 16 & 24 & 32 & 85 & 108 & 91 & 369 & 4.34 \\
\hline $\begin{array}{c}\text { Larger glazed } \\
\text { window area }\end{array}$ & 7 & 20 & 24 & 24 & 110 & 72 & 140 & 397 & 4.67 \\
\hline
\end{tabular}

Notes: Each item is measured on a 7-point scale, M scores 4 and above 4 implies spaces participants' needs spatial alteration; these are of the participants who reported either 5,6 or 7 .

Table 10: Suggested pleasant sound in single room, apartment and independent house.

\begin{tabular}{|c|c|c|c|c|}
\hline Sr. No. & Pleasant Sounds & Single room & Apartment & Independent house \\
\hline 1 & Chirping of the birds & $92 \%$ & $68 \%$ & $56 \%$ \\
\hline 2 & Sound of the flowing water & $85 \%$ & $62 \%$ & $62 \%$ \\
\hline 3 & $\begin{array}{l}\text { Sounds of raindrops from the window, making you feel } \\
\text { cosy and comfortable within the confines of your home }\end{array}$ & $69 \%$ & $54 \%$ & $62 \%$ \\
\hline 4 & Musical Instrument & $62 \%$ & $59 \%$ & $52 \%$ \\
\hline
\end{tabular}




\begin{tabular}{|c|c|c|c|c|}
\hline 5 & A cuckoo bird's melody & $54 \%$ & $34 \%$ & $38 \%$ \\
\hline 6 & Raindrops falling gently on leaves & $62 \%$ & $45 \%$ & $49 \%$ \\
\hline 7 & Sound of cool and calm breeze rustling by a tree & $85 \%$ & $62 \%$ & $53 \%$ \\
\hline 8 & Sound of bells ringing together in a religious gathering & $46 \%$ & $36 \%$ & $27 \%$ \\
\hline 9 & Sound home pets playing & $46 \%$ & $26 \%$ & $33 \%$ \\
\hline 10 & Children playing jovially & $23 \%$ & $23 \%$ & $25 \%$ \\
\hline
\end{tabular}

Table 11: Suggested pleasant aroma in single room, apartment and independent house.

\begin{tabular}{|c|c|c|c|c|}
\hline Sr. No & Olfactory Suggestions & Single rooms & Apartments & Independent houses \\
\hline 1 & The smell of freshly made coffee & $62 \%$ & $59 \%$ & $52 \%$ \\
\hline 2 & Aroma Candles & $62 \%$ & $52 \%$ & $36 \%$ \\
\hline 3 & Incense sticks & $69 \%$ & $45 \%$ & $39 \%$ \\
\hline 4 & Dried potpourri & $31 \%$ & $31 \%$ & $29 \%$ \\
\hline 5 & Fragrant houseplants & $69 \%$ & $77 \%$ & $69 \%$ \\
\hline
\end{tabular}

\section{Discussions}

It could be observed that people generally prefer extended spaces such as balcony, open terrace, courtyard and landscape indoors. All these preferences mean extra space that costs additional money. However, the paradox is that under the dwindling economic situation and lowered affordability, additional expenses are not a viable solution. However, learning from the Japanese, architects could think of multiple-use, flexible spaces that facilitate the comfort and well-being to be accomplished in the long-term containment spaces. In order to increase group and individual activities, 'vertical farming, terrace farming and balcony landscapes' offer a good choice. Despite being contained such activities motivate people to be involved and active. Further, they to an extent generate food at the place of consumption itself. Interior modifications shall consider the preferences of users; artificial vs. natural, in terms of sight, auditory, olfactory, tactile and movements. However, the artificial choices have the latent potential to be repetitive and boring in longterm. Natural choices, on the contrary, are pleasing and invigorating. However, the cost of installation, maintenance and the time require by such in upkeep would be considerable. Although such items would involve the residents in a creative manner and ameliorate boredom, in the post-pandemic situation these might turn out to be additional botheration, if not automated. Hence, careful choices and installations integrated needs to be exercised.

In new constructions, architects shall think of accommodating long-term containment requirements of residential spaces. They shall learn from 'less is more' and conceive simple, isolatable and large-span blocks with distributed facilities and support spaces and suitable technology well-integrated with built-forms, especially in institutional and apartment housing. It is appropriate to think in terms of ' $\mathrm{H}$ ', ' $\mathrm{X}$ ', and ' $\mathrm{Y}$ ' shaped residential blocks; that promote lighting and ventilation, with large spans that facilitate flexibility and required modification in times of pandemic. Governments shall think of promoting sustainable ' $\mathrm{H}$ ', ' $\mathrm{X}$ ', and ' $\mathrm{Y}$ ' shaped residential blocks with large-spans and integrate vertical landscaping and vertical/roof-top farms. Such built forms may be given 'Green incentive' and promoted. On the contrary, in the case of built forms without sustainable and pandemic constructions 'Green tax' may be imposed. Further, no relaxation in terms of 'setback' and 'inter block spacing' shall be permitted since such decisions will adversely affect lighting, ventilation and increase the potential to spread pathogens.

\section{Conclusion}

Residential space should be calm which help us to reduce stress, enhance creativity and clarity of thought, improves our mental health and physical wellbeing; as pandemic requires maintaining social distancing, self-isolation so architectural design needs to understand relation between cognition and space.

\section{References}

1. Porta M (2014) A Dictionary of Epidemiology $6^{\text {th }}$ (Edn.). Oxford University Press.

2. WHO (2020) India ramps up efforts to contain the spread of novel coronavirus. World Health Organisation.

3. Kimmelman M (2020) Can City Life Survive Coronavirus?

4. Lumen Periods of Human Development. Lumen: Lifespan Development.

5. Brazendale KBM (2017) Understanding differences between summer vs. school obesogenic behaviors of children: the structured days hypothesis. Internation Journal of Behavioral Nutrition and Physical Activity.

6. Sprang GSM (2013) Posttraumatic stress disorder in parents and youth after health-related disasters. Disaster Medical Public Health Prep pp. 105-110.

7. B Boden-Albala EL (2005) Social isolation and outcomes post stroke. Neurology 64(11): 1888-1892.

8. United Nations (2020) UN chief calls for domestic violence 'ceasefire' amid 'horrifying global surge'. UN News.

9. Vonier T (2020) COVID-19: UIA PRESIDENT'S DECLARATION. UIA

10. Arch daily (2020) Pandemic Architecture Ideas Competition Open Call.

11. Baker PC (2020) We can't go back to normal: how will coronavirus change the world?

12. BD+C EDITORS (2020) COVID-19 and real estate: How the coronavirus is impacting the AEC industry. 
13. Bernstein FA (2020) Competition Invites Architecture Students to Confront the Pandemic Through Design.

14. Budds D (2020) Design in the age of pandemics.

15. Carrington D (2020) Coronavirus: 'Nature is sending us a message', says UN environment chief.

16. Dorris J (2020) US Designers Share Ways They're Thinking Big During the Pandemic.

17. Hanley W (2020) Li Edelkoort Thinks Coronavirus Will Change Consumer Behavior Forever.

18. Kramer M (2020) The coronavirus pandemic, as seen from space. AXIOS

19. Lichfield G (2020) We're not going back to normal. MIT Technology.

20. Madhav N, Oppenheim B, Gallivan M, Mulembakani P, Rubin E, et al. (2020) Pandemics: Risks, Impacts, and Mitigation. Disease Control Priorities: Improving Health and Reducing Poverty.

21. Makhno S (2020) Life after coronavirus: how will the pandemic affect our homes? Dezeen.

22. Morley JB (2020) What does the coronavirus pandemic mean for architects? The Architect's Newspaper.

23. Neklason A (2020) A Historical Lesson in Disease Containment. The Atlantic.

ISSN: 2574-1241

DOI: 10.26717/BJSTR.2020.28.004710

Abraham George. Biomed J Sci \& Tech Res

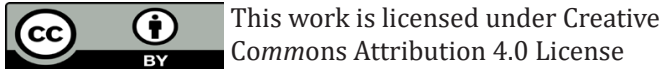

Submission Link: https://biomedres.us/submit-manuscript.php
24. Niederhäusern Gd (2020) The Architect's Dilemma at The Time of Pandemic: Should Architecture Favour Social Distance, or Foster Social Interaction? Pininfarin.

25. Nielsen D (2020) 17 Architects and Designers on How the Pandemic Will Change Our Homes Forever. Dwell.

26. Noa Pinter-Wollman A J (2018) The impact of the built environment on health behaviours and disease transmission in social systems. Philosophical Transactions of the Royal Society B: Biological Sciences p. 1-17.

27. Peters A (2020) How we can redesign cities to fight future pandemics. Fast Company.

28. Ramírez A (2020) 11 hypotheses on how life may change in a postpandemic world. M: UX Collective.

29. Ravenscroft T (2020) Five ways architects and designers are helping the fight against coronavirus. Dezeen.

30. Surico J (2020) The Power of Parks in a Pandemic. CITYLAB.

31. University of Venice (2020) PANDEMICS \& ARCHITECTURE. Copenhagen.

32. Wainwright 0 (2020) Smart lifts, lonely workers, no towers or tourists: architecture after coronavirus. The Guardian.

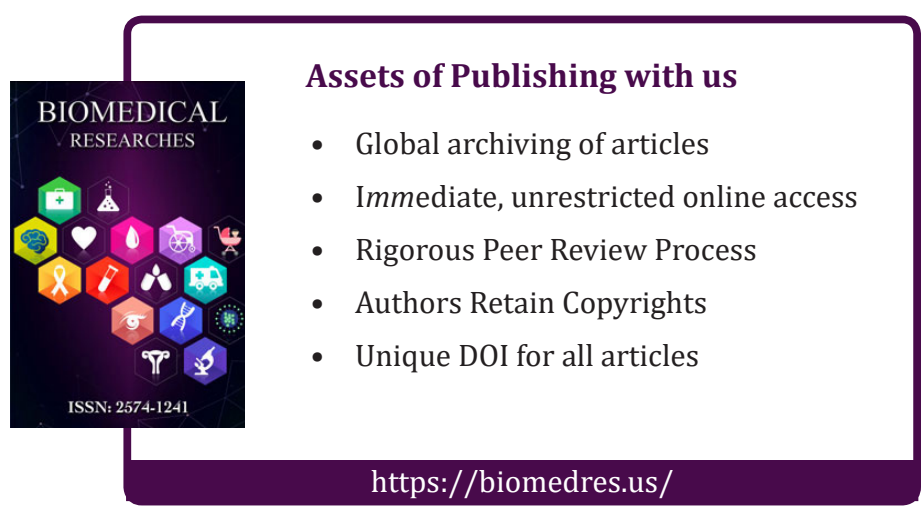

